\title{
PERFORMANCE APPRAISAL AND SUPERVISION OF STATE-OWNED ENTERPRISES IN BOSNIA AND HERZEGOVINA
}

\author{
Nikola Nikolić ${ }^{1}$, Slobodan Marin ${ }^{2}$, Milan Šušić ${ }^{3}$ \\ ${ }^{1}$ Doboj Medical School, Republic of Srpska, Bosnia and Herzegovina \\ ${ }^{2}$ Orthodox priest in Banja Luka, Republic of Srpska, Bosnia and Herzegovina \\ ${ }^{3}$ OMEGA INVEST,d.o.o. Banja Luka, Republic of Srpska, Bosnia and Herzegovina \\ direktor@vmsz.eu, o.slobodan@parohijapaprikovacka.com, i.susic51@gmail.com
}

\section{Original Scientific Paper \\ 10.5937/jouproman8-29087}

\begin{abstract}
Bosnia and Herzegovina has opted for a market economy, which implies the liberalization of prices and trade, as well as the existence of an applicable legal system, including real rights. In order for a market economy to function, it is necessary to ensure macroeconomic stability and consensus on economic policy. A developed financial sector and the absence of significant barriers to entry and exit strengthen the efficiency of the economy. By analyzing the database of financial statements of state-owned companies in Bosnia and Herzegovina, we conclude that they are mostly in poor financial condition. This paper analyzes the structure of the state-owned enterprise sector, and identifies individual enterprises that affect fiscal and macroeconomic performance. State-owned companies do not contribute enough to the growth and stability of the economy, the financial analysis showed. The framework for the management of state-owned enterprises has also been analyzed and we come to the conclusion that the entity and cantonal governments do not perform their ownership function in accordance with the WB / OECD guidelines. Quality governance reforms in state-owned enterprises are needed to encourage transparency and increase the quality of accountability. Achieving a higher level of quality in the state-owned enterprise sector can achieve an increase in total GDP of 3 percent annually.
\end{abstract}

Key words: state-owned enterprises, financial performance, enterprise management, quality, reforms.

\section{INTRODUCTION}

The economy of Bosnia and Herzegovina consists largely of state-owned enterprises, which have a significant impact on macroeconomic stability, including its fiscal stability, labor market stability and competitiveness ${ }^{1}$. State-owned companies are inherited from the former Yugoslavia. The civil war, which lasted from 1992 to 1995 and was interrupted by the Dayton Peace Agreement of 1995, led to further decentralization of state-owned enterprises in accordance with the organization of the state of Bosnia and Herzegovina, into two entities: Republic of Srpska, Federation of Bosnia and Herzegovina and ten cantons in the Federation of Bosnia and Herzegovina, Brcko District and 145 municipalities. Most state-owned enterprises were privatized from 1996 to 2006, but the public considers the results of the privatizations unsatisfactory, due to a number of unsuccessful high-profile privatizations.

\footnotetext{
${ }^{1}$ In Bosnia and Herzegovina, a uniform definition of SOEs has not been achieved at the level of all levels of government. The definition of stateowned enterprises in the Republic of Srpska is regulated by the Law on Public Enterprises, Official Gazette of the RS, 75/04, 78/11, and in the Federation of Bosnia and Herzegovina by the Law on Public Enterprises, Official Gazette of the FBiH, 08/05, 81/08, 22/09.
} 
The legal framework of the former Yugoslavia governing SOE was modernized during this period, but it is considered that the management and supervision of this sector lacks responsibility. There are no high-quality, up-to-date and publicly available databases on the state-owned enterprise sector. The analysis showed that state-owned enterprises participate with approximately 11 percent of total employment, but somewhat less participate in value-added (only 10 percent).

One of the objectives of the paper is to determine the size and structure of the sector of state-owned enterprises in Bosnia and Herzegovina. In order to achieve the set goal, it was necessary to create a database of state-owned companies for the period from 2015 to 2017. The second set goal is to analyze the financial performance of the overall sector of state-owned enterprises and individual ente-rprises. Financial ratio analysis (profitability, leverage and liquidity) was used to identify individual firms that pose financial risks to governments.financial performance of the overall sector of state-owned enterprises and individual enterprises. Financial ratio analysis is used to identify individual companies that pose financial risks to governments ${ }^{2}$.

One of the objectives is to analyze the ownership function of governments and their policies to oversee, identify weaknesses and opportunities to improve them. A survey method was used to determine the quality of management of state-owned enterprises in relation to the region and the recommendations of the World Bank and the OECD in the following areas: a) ownership and governance framework; b) financial

\footnotetext{
${ }^{2}$ Renteria, et, al. (2018).
}

supervision; and c) fiscal and policy interactions that companies have with government $^{3}$. The paper discusses the performance and governance issues for certain sectors of state-owned enterprises in Bosnia and Herzegovina.

State-owned enterprises (SOEs) have a significant impact on the economy, but a large number of these enterprises have a negative impact on macroeconomic indicators

„The analysis shows that approximately 80,000 workers are employed in 550 stateowned enterprises in all sectors of the economy, accounting for 11 percent of total employment. State-owned enterprises own approximately 40 percent of all fixed assets and are responsible for 10 percent of total turnover. State-owned enterprises are disrupting the labor market because their average wages are 40 percent higher than the wages of private enterprises, even though they have lower productivity. Total SOE debts amount to approximately $26 \%$ of GDP. Stateowned companies in Bosnia and Herzegovina have the third highest salary premium in the region" ${ }^{\text {" }}$.

„Aggregate SOE debts amount to about 26 percent of GDP. This includes close to 4 percent of GDP in overdue arrears of taxes and social contributions, which reduces tax revenues and has a negative impact on the functioning of the social benefits system. The financial ratio analysis shows that over 44,000 people are employed in state-owned enterprises (SOEs) that face high or very high financial risks (6 percent of total employment) ${ }^{65}$.

\footnotetext{
${ }^{3}$ Bower, (2017).

${ }^{4}$ Richmond, et, al. (2019).

https://www.imf.org/en/Publications/Depa rtmental-Papers-PolicyPapers/Issues/2019/06/17

${ }^{5}$ Internet: www.imf.org
} 
Figure 1 shows the added value in relation to employment in 2016 for state-owned enterprises for the countries of Central and Eastern Europe ${ }^{6}$.

This paper determines the impact that the state-owned enterprise sector has on the economy of Bosnia and Herzegovina, such as: sector size, sector structure, financial indicators, labor markets.

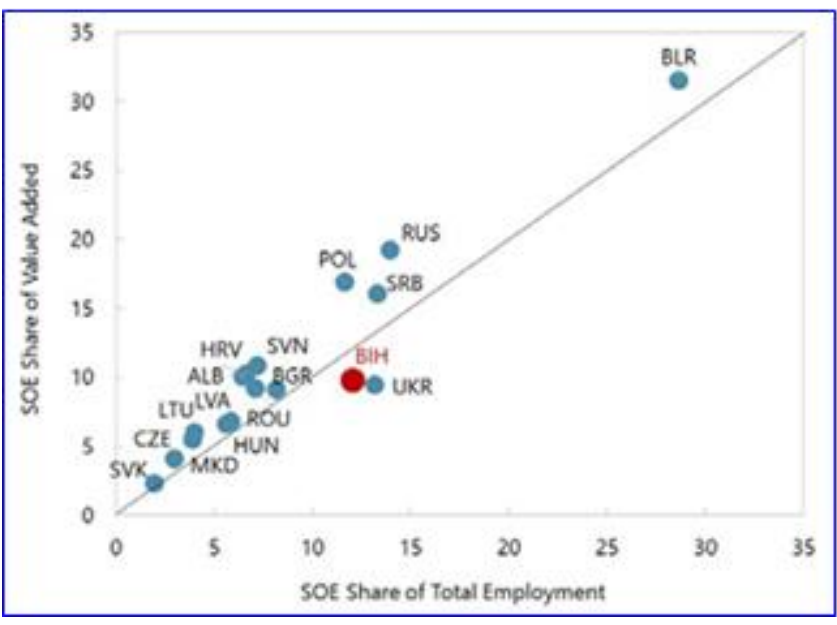

Figure 1. Value added in relation to employment, in Bosnia and Herzegovina, 2016 in ,State-Owned Enterprises in Central Eastern and South Eastern Europe“"7

$\mathrm{S}$ aggregate amounts mask performancerelated challenges in individual enterprises, financial ratio analysis will be used in the paper to identify high-risk state-owned enterprises. To assess the risk of state-owned enterprises, the following financial indicators are taken into account: profitability, leverage and liquidity. „The paper analyzes the entity frameworks for the management of state-owned enterprises (SOEs), and then considers options for improving the performance of the state-owned enterprises (SOE) sector ${ }^{\star 8}$

\section{QUANTITATIVE ANALYSIS OF}

\footnotetext{
${ }^{6}$ Richmond, el. at. (2019).

${ }^{7}$ Internet: www.imf.org

${ }^{8}$ Perkins , (1996).
}

\section{STATE ENTERPRISES IN BOSNIA AND HERZEGOVINA}

There are over 550 state-owned enterprises (SOEs) in Bosnia and Herzegovina. There is no single register at the level of Bosnia and Herzegovina, although there are centralized registers of state-owned enterprises in the $\mathrm{FBiH}^{9}$. The database of financial statements includes the entity, cantonal and municipal levels. Our quantitative analysis is based on a sample of 414 companies for the period from 2014 to $2017^{10}$. „Therefore, we have information for nearly 80 percent of SOE, but we probably cover more than 90 percent of SOE by income, employment, or resources, as data is more likely to be available to larger enterprises“"11. „However, most of the economic activity is performed by SOEs owned by the entity central governments, which in 2017 generated about 85 percent of SOE revenue ( $€ 2.9$ billion), held 85 percent of SOE assets and liabilities and EUR 3.5 billion, respectively), and employed 58 thousand out of 76 thousand total SOE employees in the sample“"12. The largest state-owned enterprises are owned by the entity governments in the electricity generation sector (Federation of Bosnia and Herzegovina and Republic of Srpska Elektroprivreda), mining (coal mines in $\mathrm{FBiH}$ ), production (weapons production), agriculture (RS Forests) and transport (roads), highways, railways).

\footnotetext{
9 The FBiH Company Registration Agency (Agency for Financial Information of the Federation of $\mathrm{BiH}$, FIA) published the SOE list in FBiH in June 2019. (https://fia.ba/)

10 Register of business entitieshttps:

https://www.apif.net/index.php/bs/registri/registarposlovnih-subjekata.html

${ }^{11}$ Internet: www.imf.org

12 Internet: www.imf.org
} 
Figure 2 shows the number of state-owned enterprises (SOEs) in Bosnia and Herzegovina.
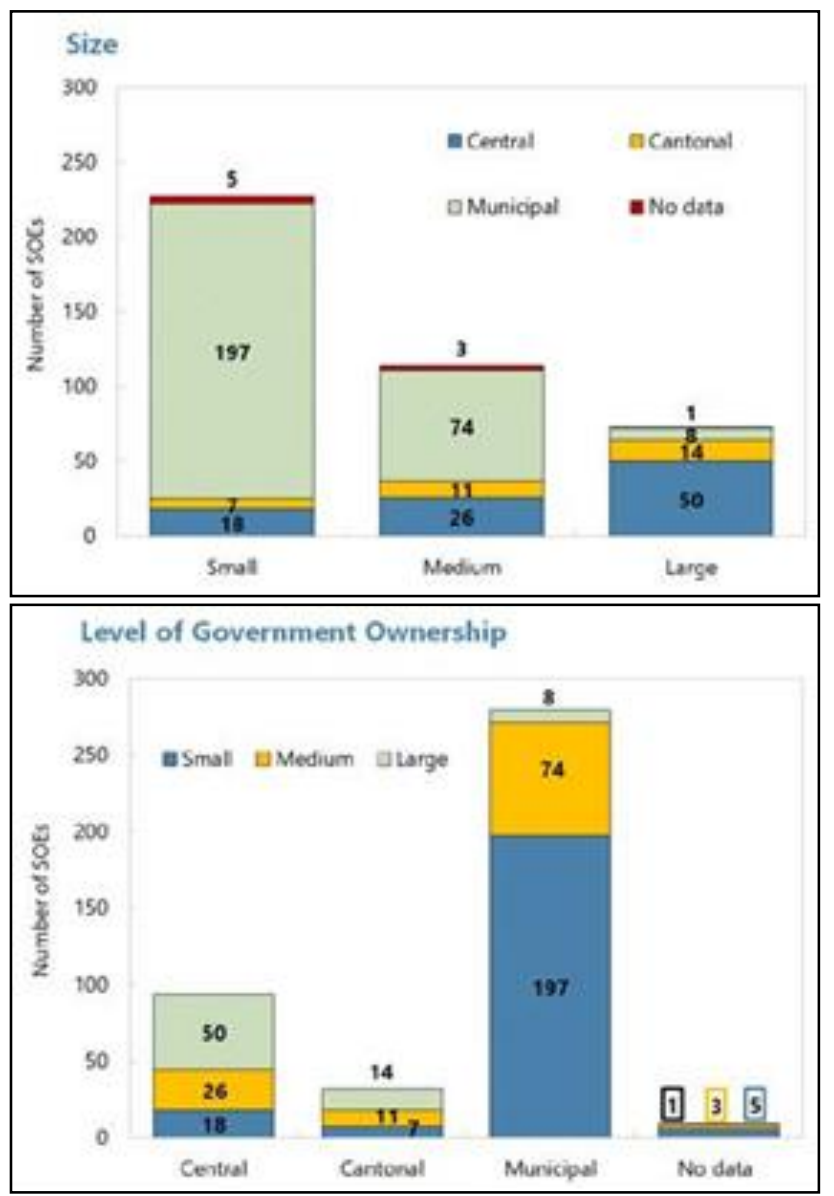

Figure 2. Overview of the number of state-owned enterprises (SOE) in Bosnia and Herzegovina (source: Competent institutions in the country and calculation the author's (2020). (https://www.blberza.com/Pages/Default.aspx)

Register of Business Entities of $\mathrm{BiH}$ (https://bizreg.pravosudje.ba/pls

/ apex / f? p = 183: 20: 6232106962533052), official government documents, and the SOE website.

The largest part of revenues and funds is in the sectors of electricity, gas, steam and air conditioning. These state-owned enterprises generate 45.6 percent of total SOE revenues, followed by information and communications (12.4 percent) and transportation of goods and storage of goods (11.7 percent). „These state80 owned enterpri-ses generate 45.6 percent of total SOE revenues, followed by information and communications (12.4 percent) and transportation and storage (11.7 percent). The three state-owned enterprises with the highest average revenues in the sample period are Elektroprivreda BiH (EUR 535 million), BH Telecom (EUR 274 million) and Elektroprivreda RS (EUR 210 million). More than 70 percent of all state-owned assets are concentrated in the electricity, gas, steam and air conditioning sectors (37 percent), and transportation and storage (36 percent) ${ }^{\text {“13. }}$.

Table 1. Observation of the sample of state-owned enterprises (number companies, revenues in millions of EUR, assets in millions of EUR, number Employments in 2017 (Authors 2020)

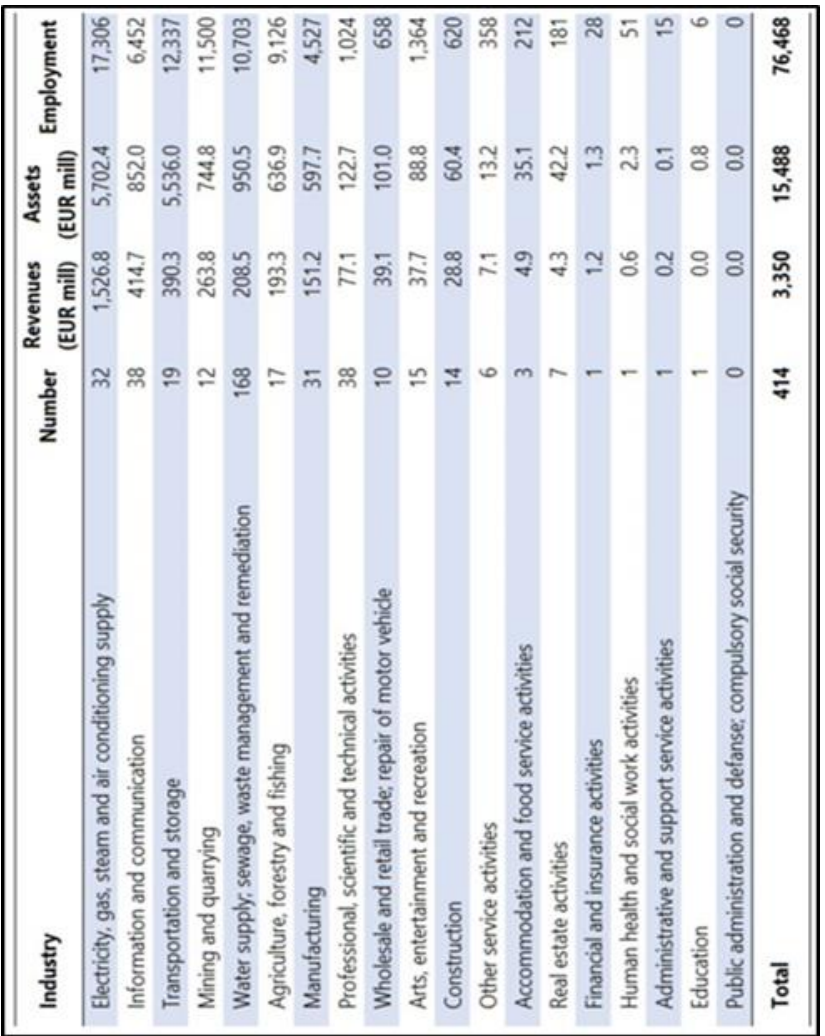

${ }^{13}$ Internet: www.imf.org 
Analyzing the observed sample of 414 state-owned enterprises, we conclude that they employ 76,468 workers and represent approximately $11 \%$ of total employment in Bosnia and Herzegovina. The database of state-owned enterprises allows us to better assess the importance of the public sector. The observed are state-owned companies in 2017 have an asset value of EUR 15,488 million, and generated revenue of EUR 3,350 million.

Figure 3 shows the employment dynamics in state-owned enterprises and the private sector, for the observed sample, in thousands of employees in the period 2015-2017.

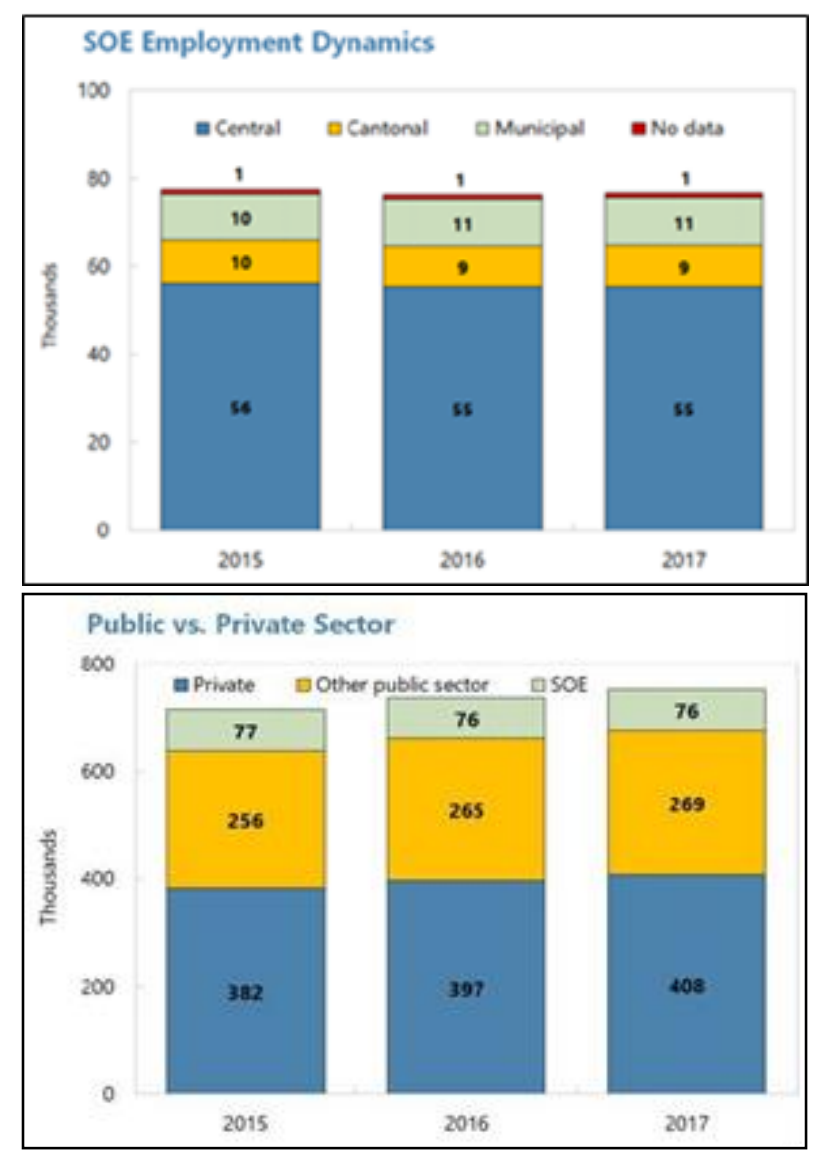

Figure 3. Employment in SOEs and private Sector (thousands workers, from years 2015-2017).

Source: Statistical Office of RS and FBiH, Authors, 2020)

„Most of the employment in SOE is concentrated in the production of goods and services. About 37 percent of SOE employment is concentrated in the electricity and water sectors $(28,000$ workers $)$, transportation $(12,000)$ and mining $(12,000)$. The five largest employers of state-owned companies are Elektroprivreda $\mathrm{BiH}, \mathrm{FBiH}$ Railways, RS Railways and the Banovići and Kreka coal mines“14. „It is interesting that $\mathrm{BiH}$ seems to be the only country in the region where the number of employees in state-owned companies has increased since 2005, and is ranked third in terms of the number of employees in state-owned companies expressed as a percentage of total

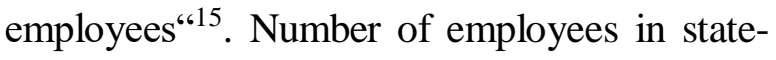
owned enterprises has steadily increased since 2005 compared to the region, and Bosnia and Herzegovina ranks third in the number of employees in state-owned companies as a percentage of total employees ${ }^{16}$. This phenome-non can be explained by the significantly lower volume of privatization in Bosnia and Herzegovina compared to other observed countries of Central and Southeast Europe in the observed period.

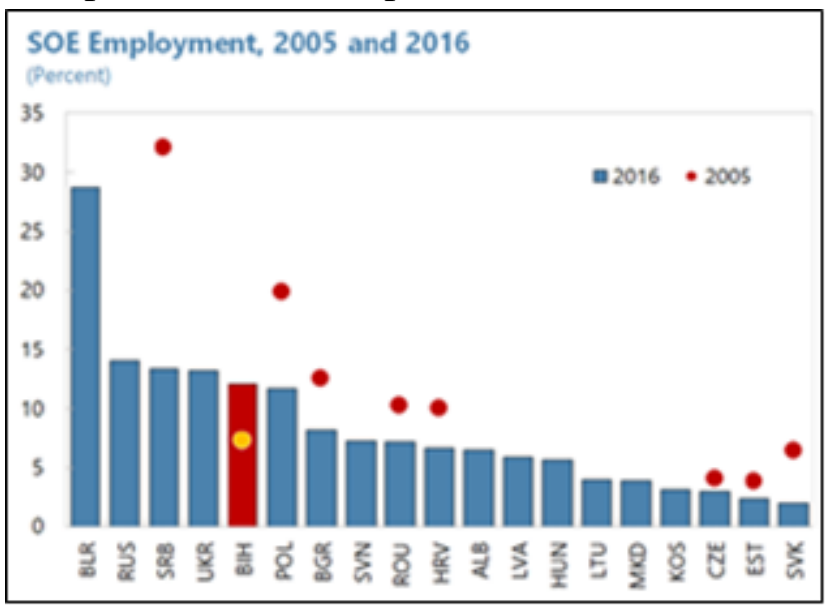

Figure 4. State-owned enterprises, employme-nt 2005, 2016 in percent (Sources: Richmond, et al. (2019); Competent institutions in the country, and the calculation of the Author 2020.)

\footnotetext{
${ }^{14}$ Internet: www.imf.org

${ }^{15}$ Stankovic, et.al. (2015).

${ }^{16}$ Richmond, et.al. (2019.)
} 


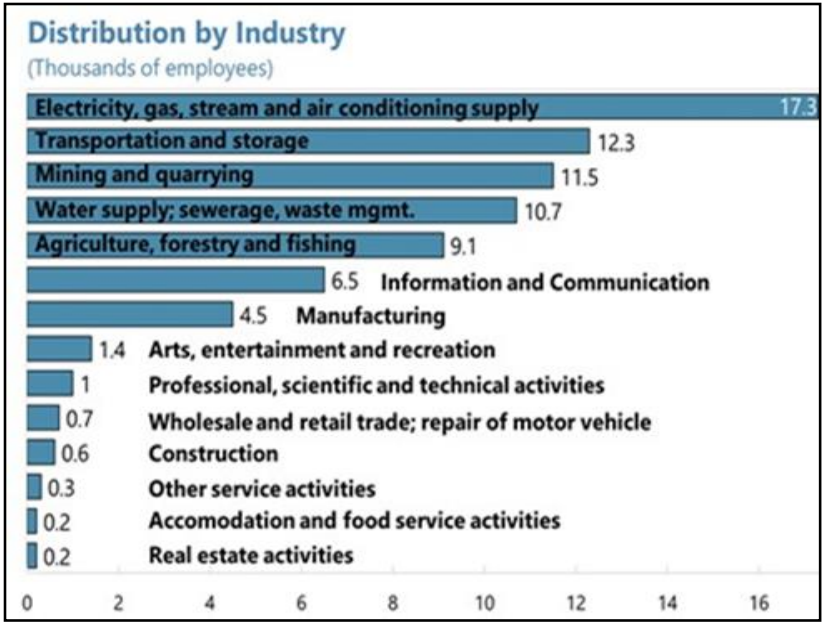

Figure 5. Distribucion by Industry (thousands employees), (Authors, 2020.)

„The balance sheet of the state-owned enterprise sector indicates significant structural weaknesses, which could require policy measures in the short term. While about 85 percent of state-owned companies are over the year 2017 was solvent, with a positive capital of around EUR 1 billion, there are 66 companies that accumu-lated losses in the amount of EUR 1.6 billion, which erased the value of their capital. These companies are technically insolvent, with negative capital totaling EUR 290 million (2 percent of GDP). The state-owned companies with the largest negative capital at the end of 2017 are the Public Transport Company Sarajevo (GRAS), with a negative capital totaling EUR 106 million (1.1 percent of the FBiH GDP), and the Central Heating Company Sarajevo (EUR 44 million). ie 0.45 percent of the FBiH GDP), and the Heating Company in Prijedor (EUR 6.4 million) ${ }^{\text {“17 }}$.

In order to significantly reduce the accumu-lated losses by sectors, it is necessary to do significant financial restructuring, which will provide additional fresh capital, in order to

${ }^{17}$ Internet: www.imf.org improve the solvency of these companies. The largest accumulated losses are in: mining, manufacturing and energy sector (Figure 6).

„State-owned enterprises have a negative impact on macroeconomic performance and do not contribute enough to the economy, due to low profitability, high leverage, and low liquidity. The debt of state-owned enterprises totals EUR 4 billion (26 percent of GDP), and through significant overdue tax arrears, these enterprises affect pension and health insurance systems. Almost half are illiquid and rely on state support, both implicit and explicit, to stay afloat" ${ }^{* 18}$.

\footnotetext{
${ }^{18}$ Internet: www.imf.org
} 


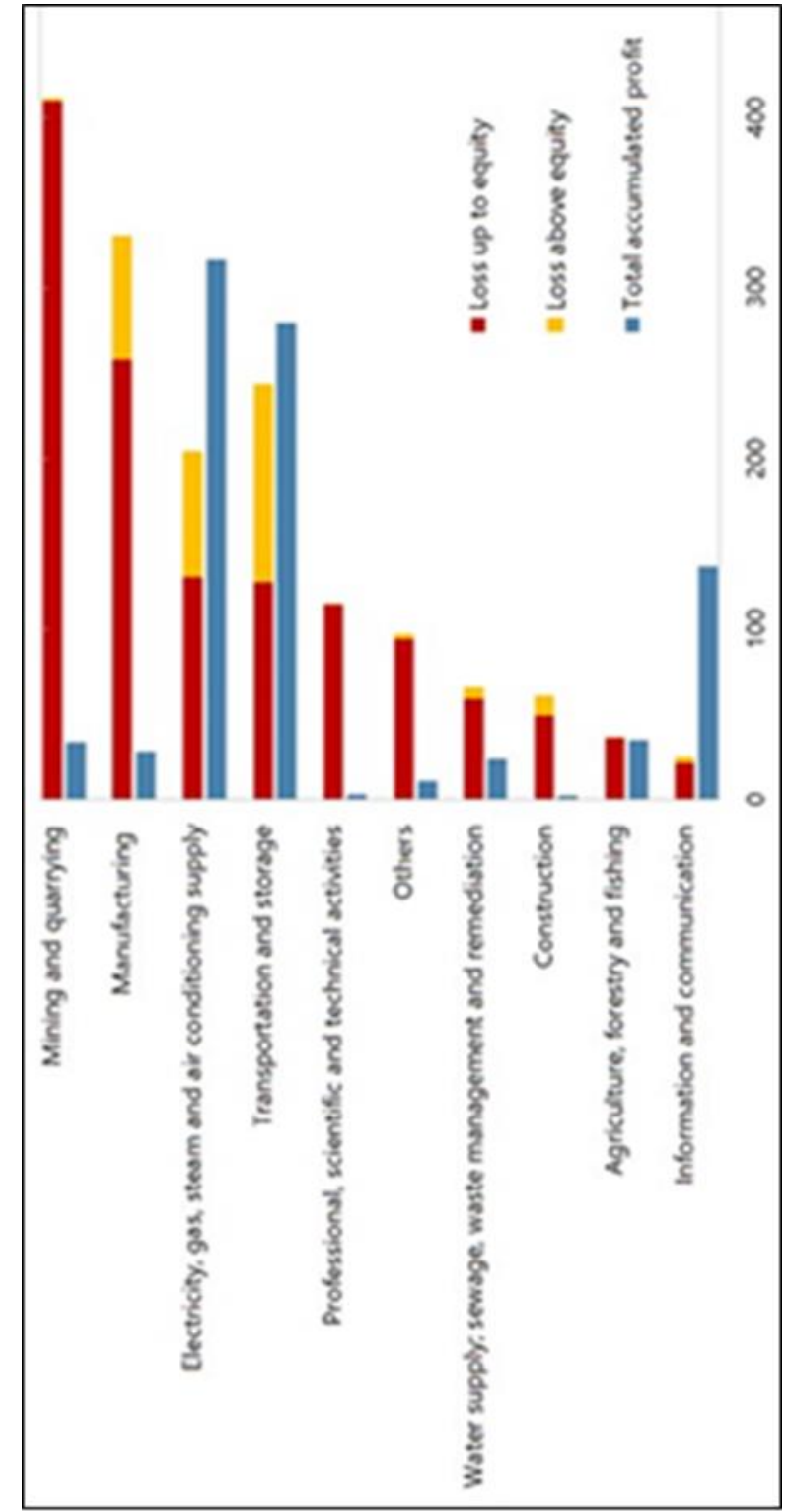

Figure 6. Accumulated losses and profit by sector of the economy, 2017 (in millions of EUR), (Autors, 2020.)

The total debt of state-owned enterprises in 2017 is at the level of 26 percent of GDP. (Figure 7). „Tax arrears should be deducted from the total liabilities of stateowned enterprises, in order to estimate the net debt to other sectors of the economy. A broader definition of indebtedness, such as total public sector debt, would allow a more accurate assessment of debt sustainability. General government debt, including guarantees, in 2017 amounted to about 40.50 percent of GDP“19.

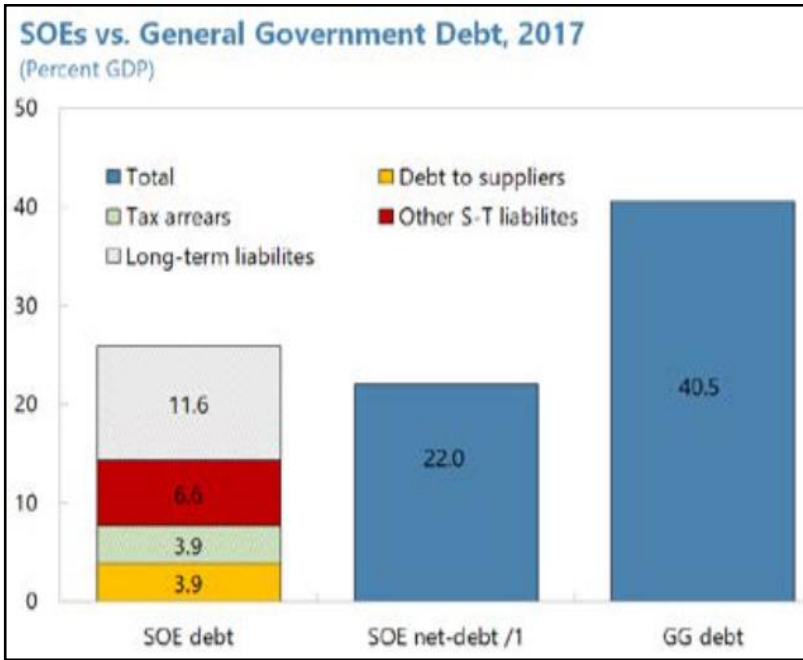

Figute 7. SOEs vs General Government Debt 2017. Years. (Authors 2020.)

Liabilities of state-owned enterprises (long-term liabilities, short-term liabilities) and debt /GDP ratio (as a percentage) in the period 2014-2017. years are shown in Figure 8 .

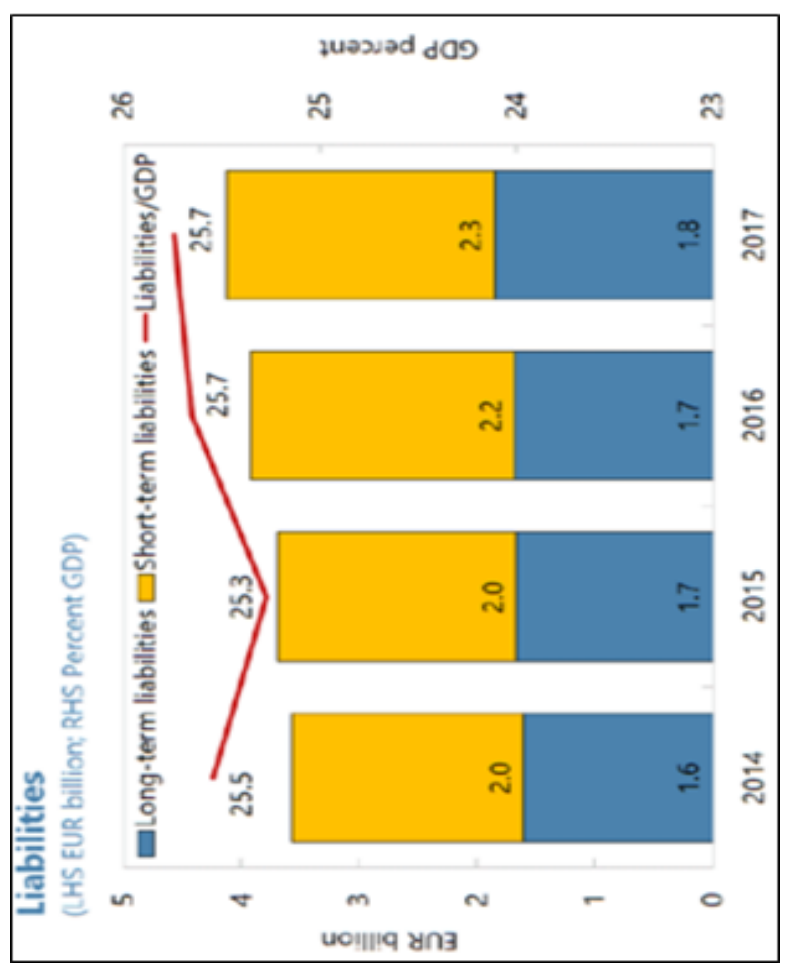

Figure 8. SOE debts and percentage of SOE / GDP for the observed period (Authors, 2020. years).

${ }^{19}$ Internet: www.imf.org 
Analyzing the above data, it can be concluded that long-term and short-term liabilities have been growing since 2015, and their share in GDP in 2017 is $25.7 \%$.

The structure of liabilities of state-owned enterprises by activities is shown in Figure 9.

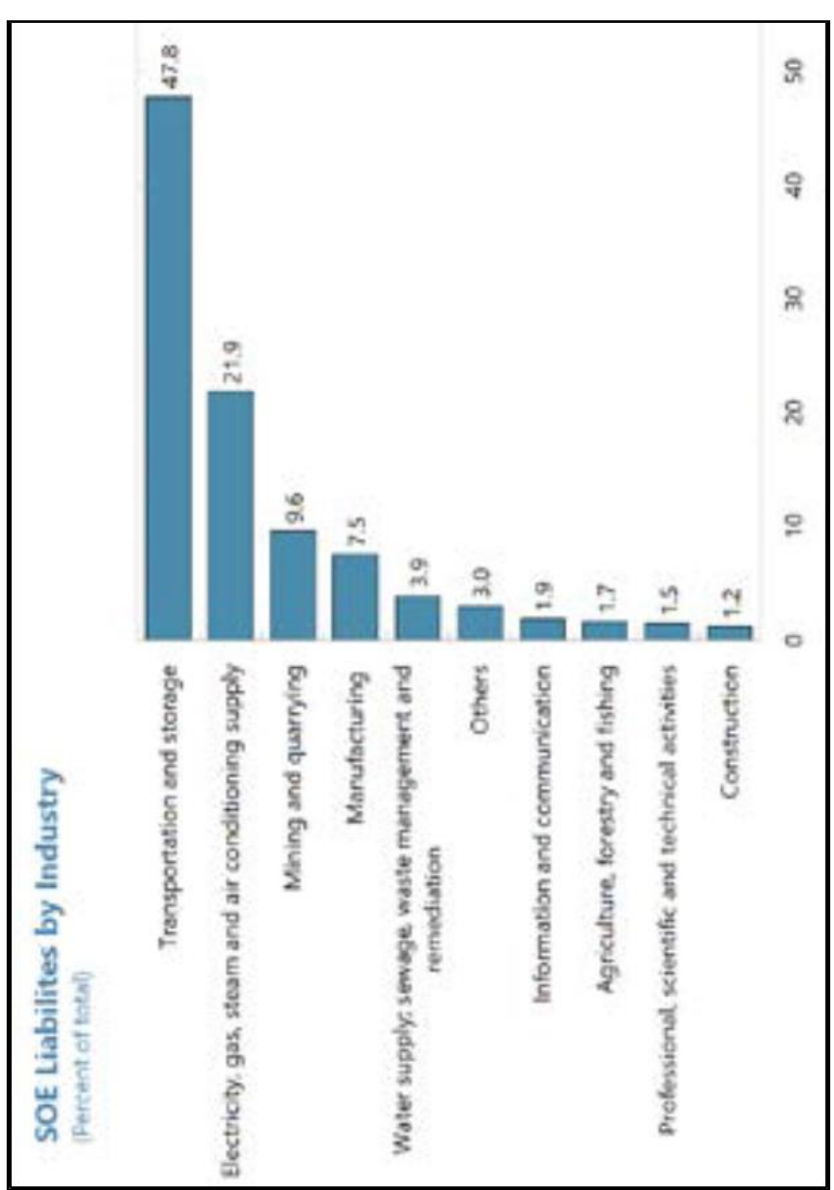

Figure 9. SOE Liabilities by Industry (percent of total) in 2017. years, (Authors, 2020.).

Analyzing the above data from Figure 9. it can be concluded that the largest liabilities by activities have the following stateowned enterprises: transport and storage (47.8\%), supply of electricity, gas and air conditioning $(21.9 \%)$, mining and quarrying $(9.6 \%)$, manufacturing $(7.5 \%)$, information and communication (1.9\%), construction $(1.2 \%)$.
In the period from 2015 to 2017, the stateowned enterprise sector produced losses on average (Figure 10). The public sector as a whole was on the verge of profitability in 2017 , out of the ten sectors analyzed, only three sectors were profitable during the period from 2015 to 2017.

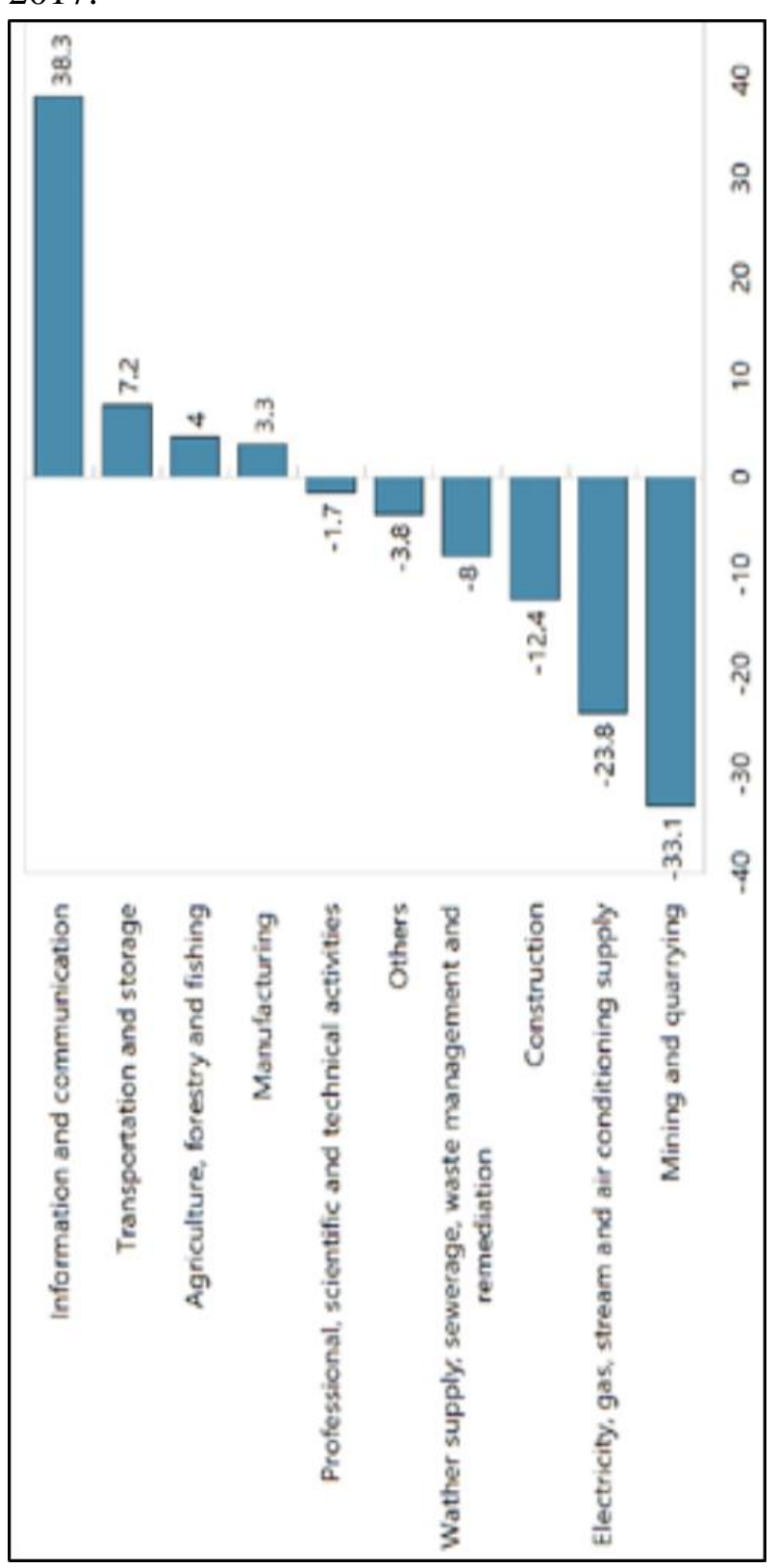

Figure 10. Net SOE income by sector of the economy, for the period from 2015 to 2017 (in millions of EUR), (Autors, 2020.) 
The most profitable commercial sector was the information and communication sector (EUR 38.3 million, or 0.4 percent of GDP in $\mathrm{FBiH}$ ), due to the profit made by $\mathrm{BH}$ Telecom, which amounted to more than three quarters of the sector's profit. Other profitable sectors were: transport and storage $(0.0075 \%$ of GDP), agriculture, forestry and fishing ( $0.0042 \%$ of GDP) and manufacturing $(0.0035 \%$ of GDP). In contrast, the electricity, gas and air conditioning supply sector recorded a loss of $0.025 \%$ of GDP, while the ore and stone extraction sector recorded large losses totaling 0.0346 percent of GDP.

\section{QUALITY OF INVESTMENTS AND OF INFRASTRUCTURE OF STATE- OWNED ENTERPRISES}

Investments of state-owned companies in 2017 amounted to $1.7 \%$ of GDP. The largest infrastructure investment projects in Bosnia and Herzegovina are carried out by state-owned companies in the energy and transport sectors (highways). Stateowned enterprises have a monopoly in the road, railway and airport sectors, as well as in electricity and telecommunications.

"The total investment of state-owned enterprises in 2017 amounted to about EUR 500 million and three sectors invested almost $86 \%$ of that amount: electricity (49.8\%), transport and storage (19 \%), and information and communications, $6 \%$ ). However, stateowned enterprises have invested only EUR 274 million (1.7 \% of GDP) in nonfinancial assets. The state-owned enterprises with the largest investments are the Public Company Highways RS (EUR 67.3 million), BH Telecom (EUR 30.9 million), and Elektroprivreda BiH (EUR 23.0 million) $)^{6}$.

The availability of public using infrastructures was analyzed using the followings criteria:1. Education; 2. Electricity consumption; 3. Built roads in the unit measuring $\mathrm{km}$ per 1000 inhabitants; 4. Quality of the health system; 5. Drinking water supply (in\% of population).

Figure 11 shows the availability of public infrastructure and the quality of infrastructure ${ }^{21}$.

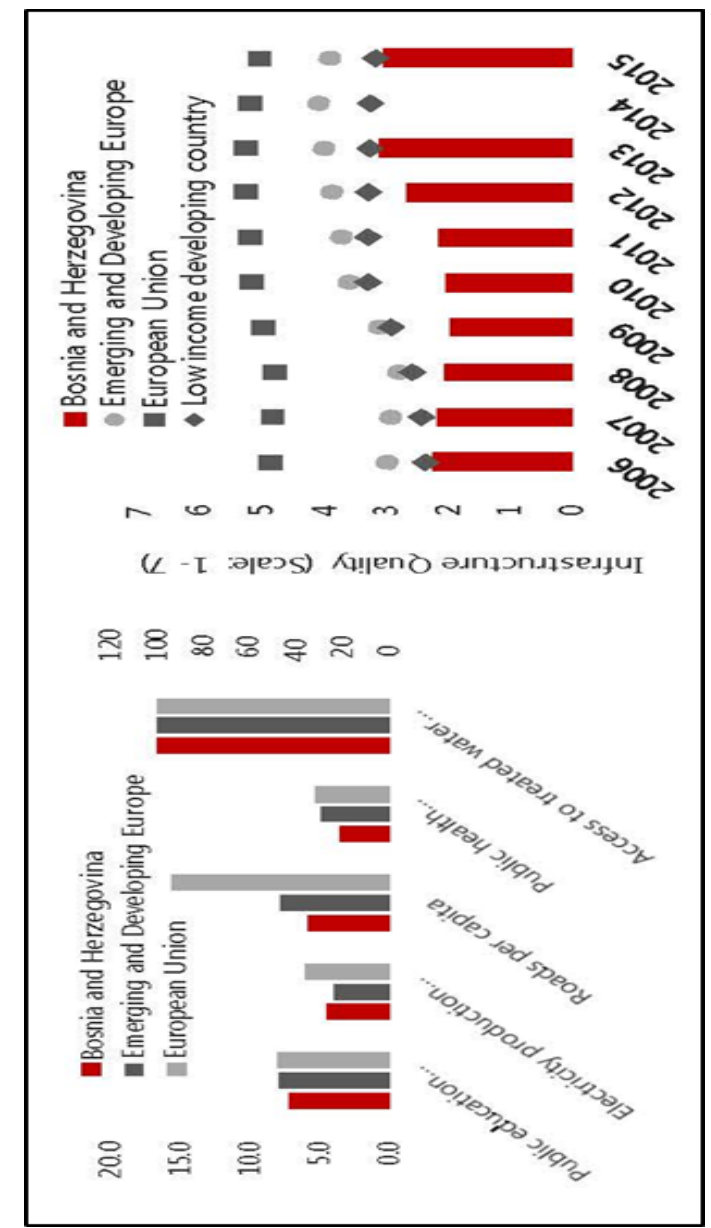

Figure 11. Availability of public infrastru-cture and views on infrastructure quality (source: World Economic Forum (2015). Global development indicators).

\footnotetext{
${ }^{20}$ Internet: www.imf.org

21 World Economic Forum (2015). Global development indicators.
} 
The results of the research show that Bosnia and Herzegovina, out of five possible indicators, is in the rank of the European Union and Europe in emerging and developing in two criteria, namely: criterion.1. Education (number of teachers in secondary schools per 1000 persons) and criterion 5. Drinking water supply (\% of population with access to clean water).

The criterion of access to public infrastructure shows us that Bosnia and Herzegovina lags significantly behind EU member states. In the period from 2014, there was an improvement in the quality of infrastructure, but it is, according to the results of the World Survey on the Quality of Economic Infrastructure (from 2015), still far below that in comparable countries. The quality of infrastructure is measured on a scale of 1-7, and it is rated on average with a score of 2.2. In the European Union, the rating of infrastructure quality is 5.5 .

The quality of infrastructure in Bosnia and Herzegovina is not at a satisfactory level, measured in relation to the European Union and the countries of the Western Balkans, although state-owned enterprises account for $16 \%$ of total investments.

\section{FINANCIAL RATIO ANALYSIS AND RISK ANALYSIS}

The results of the research show that the financial indicators of the state-owned enterprise sector compared to the overall economy of Bosnia and Herzegovina are not satisfactory. Indicators of profitability, leverage and liquidity indicate a weak performance of state-owned enterprises compared to the private sector (Table 2).
Profitability indicators (ROE and ROA) indicate that state-owned enterprises generate negligible value from the funds available to them. „State-owned enterprises also have a higher leverage than the private sector, and their liquidity is lower than that of the private sector. These indicators point to the need to continue government support for a number of state-owned enterprises in the short term" ${ }^{\prime 22}$.

State-owned enterprises have a higher leverage than the private sector, and their liquidity is lower compared to the private sector. On the basis of such criteria calculated, the government needs to urgently intervene with short-term investments in a number of state-owned enterprises.

Table 2. Selected financial ratios (Authors, 2020)

\begin{tabular}{|lrrrr|}
\hline & SOEs 2015 & SOEs 2016 & SOEs 2017 & Economy 2017 \\
\hline ROE & -1.0 & -0.1 & 0.3 & 5.9 \\
Debt/EBITDA & 9.7 & 7.8 & 7.6 & 6.4 \\
CLR & 0.9 & 0.8 & 0.8 & 1.1 \\
ROA & -0.7 & -0.1 & 0.2 & 2.8 \\
\hline \hline
\end{tabular}

„We will assess the quality of finances for individual state-owned enterprises using unique criteria. In this way, we will assess the financial difficulties of certain state-

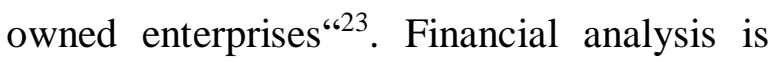
key in a comprehensive assessment of the performance of state-owned enterprises. The assessment of the financial condition of certain state-owned enterprises was done using the following financial indicators:

- Profitability - Return on capital. This indicates whether the company generates a profit that covers the opportunity cost of capital.

\footnotetext{
22 Internet: www.imf.org

${ }^{23}$ Internet: www.imf.org
} 
- The loss-making companies, profitabilityit indicates how quickly capital is corroded.

- Lever - Debt to EBITDA ratio ${ }^{24}$. This measures the company's ability to cover its debt obligations (an approximate indicator of how many years it would take the company to repay all debts from earnings from operating activities).

- Liquidity - This indicator measures the ability of an enterprise to meet its short-term liabilities using its shortterm assets (short-term assets are defined as assets with a maturity of less than one year). If the indicator is less than 1, then it indicates that financial support is needed for a stateowned enterprise to meet its short-term obligations.

In Table 3, each state-owned enterprise is classified classified into one of five groups, depending on the value of the results obtained according to the given criteria.

The results of the analysis show that $49 \%$ of state-owned enterprises operate with high or very high risks according to the criterion of profitability (Figure 12).

„The analysis also shows that mediumsized state-owned enterprises and cantonal state-owned enterprises face somewhat higher risks measured by the criterion of profitability than large enterprises ${ }^{\text {}} 25$.
Tabela 3. Risk scale map (Reteria et el. 2018.)

\begin{tabular}{|clc|}
\hline Profitability - Return of Equity & Very high risk & $<-10 \%$ \\
& High risk & $-10 \%-0 \%$ \\
\cline { 2 - 3 } (Net Income / Average Equity) & Moderate risk & $0 \%-8 \%$ \\
& Low risk & $8 \%-15 \%$ \\
& Sound & $>15 \%$ \\
\hline \hline Leverage - Debt to EBITDA Ratio & Very high risk & $>5$ \\
& High risk & $3-5$ \\
\cline { 2 - 3 } (Total Liabilities / EBITDA) & Moderate risk & $2-3$ \\
& Low risk & $1.5-2$ \\
& Sound & $<1.5$ \\
\hline \hline \multirow{2}{*}{ Liquidity - Current Ratio } & Very high risk & $<1$ \\
& High risk & $1-1.2$ \\
\cline { 2 - 3 } & Moderate risk & $1.2-1.5$ \\
(Current Assets / Short-term Liabilites) & Low risk & $1.5-2$ \\
& Sound & $>2$ \\
\hline \hline
\end{tabular}

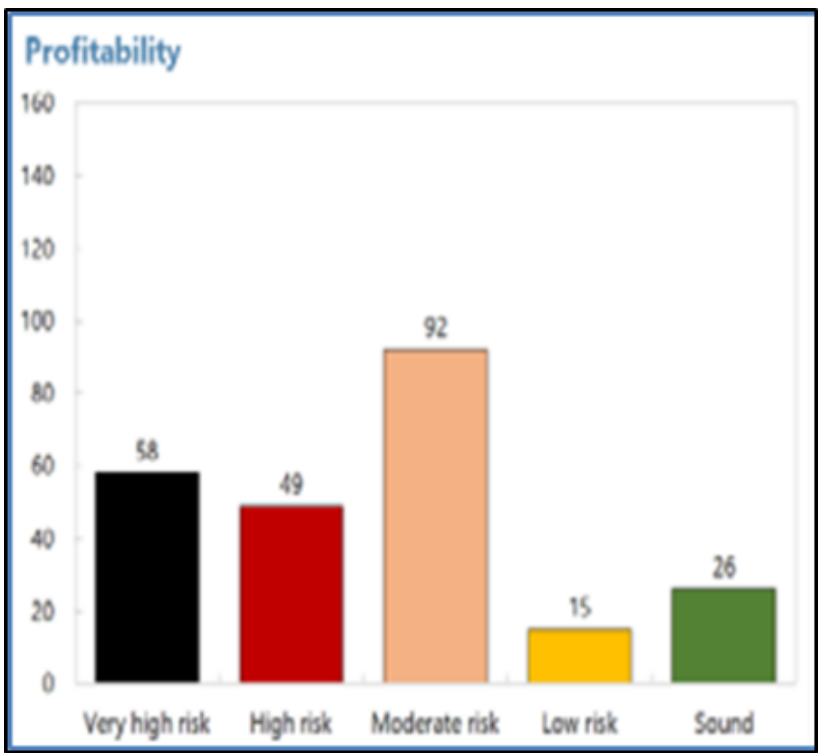

Figure 12. Analysis of financial profitability risks for SOE in $\mathrm{FBiH}$ (SOE number) (Autors, 2020)

A total of 58 state-owned companies in the $\mathrm{FBiH}$ are in the categories of very high risk to profitability, and 49 companies are in high risk.

In the Republic of Srpska, a total of 52 state-owned enterprises are in the categories to very high profitability risk, and 43 enterprises are in the category of high profitability risk (Figure 13).

\footnotetext{
${ }^{24}$ Internet: www.imf.org.

${ }^{25}$ Internet: www.imf.org
} 


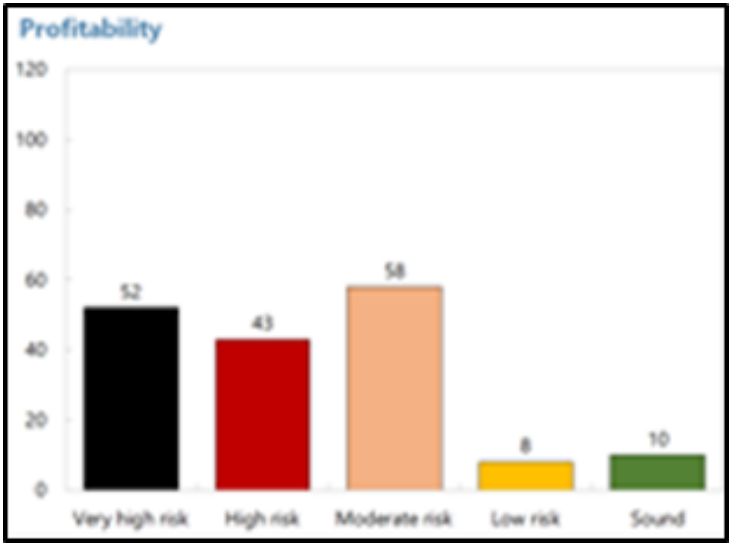

Figure 13. Analysis of financial profitability risks for SOE in RS (SOE number) (Autors, 2020)

The ability of state-owned enterprises to cover their debt obligations - leverage is at a very high and high risk in the $\mathrm{FBiH}$ (175 companies), as well as in the Republic of Srpska (143 companies) (Figure 14).
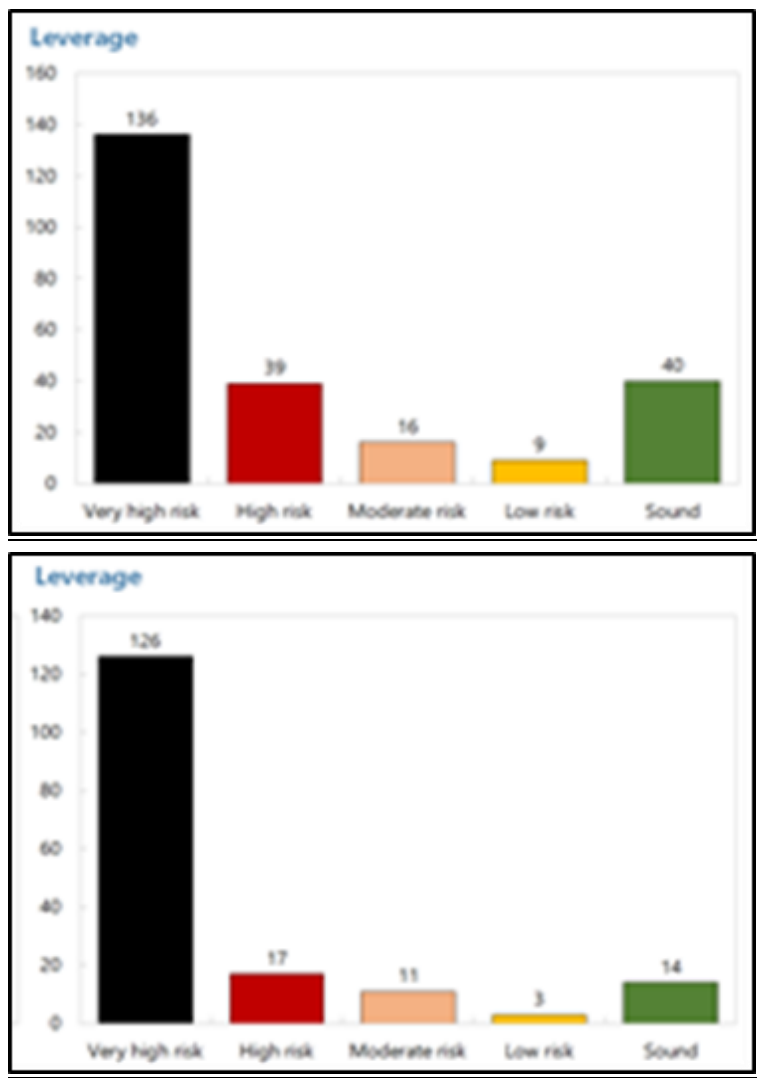

Figure 14: Analysis of the ability of state-owned enterprises to cover their debt obligations in the FBiH and RS (SOE number) (Authors, 2020)
Risk analysis - liquidity of state-owned enterprises is at very high and high risk in the $\mathrm{FBiH}$ (108 enterprises), as well as in the Republic of Srpska (98 enterprises) (Figure

$15)$.

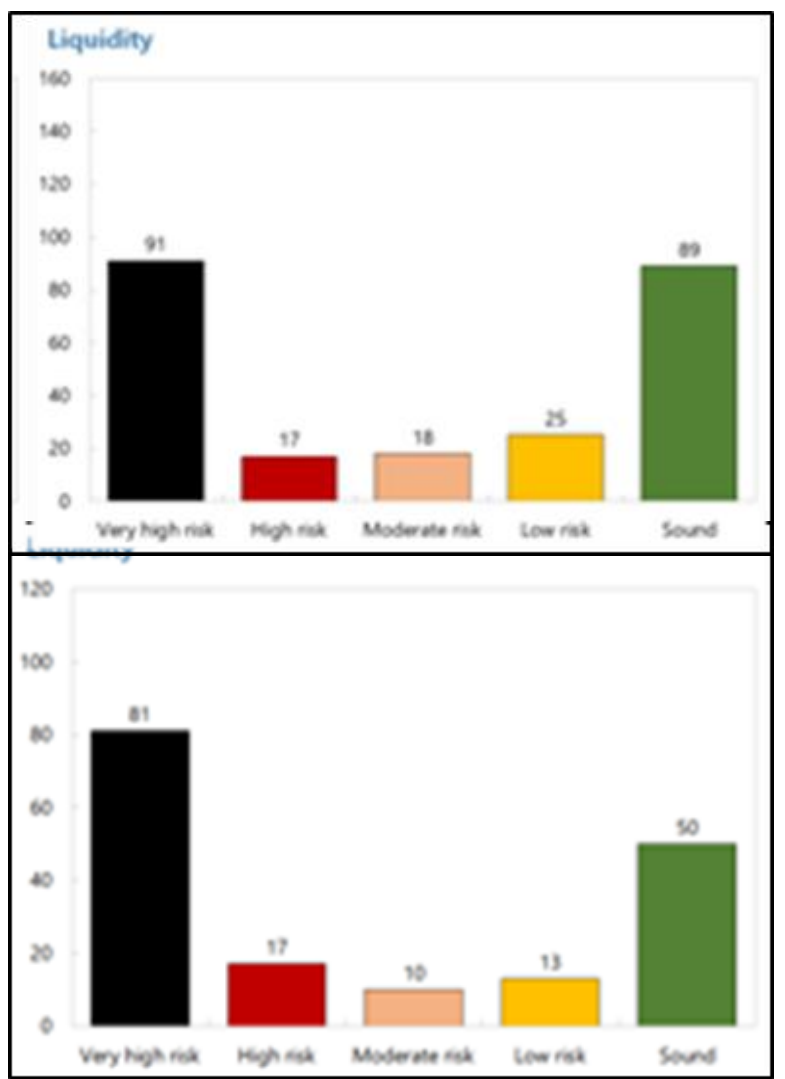

Figure 15: Risk analysis - liquidity of state-owned enterprises in FBiH and Republika Srpska (SOE number) (Authors, 2020)

$\mathrm{He}$ analysis shows that $49 \%$ of stateowned enterprises face high or very high risks measured by the profitability criterion (Figure 16). „Medium-sized stateowned ente-rprises and cantonal stateowned enterprises face slightly higher profitability risks than large enterprises. The sectors with the highest profitability risks (ranked as high or very high) are manufacturing (77 percent), mining (75 percent), construction (64 percent), and transportation (53 percent) ${ }^{، 26}$.

${ }^{26}$ Internet: www.imf.org 


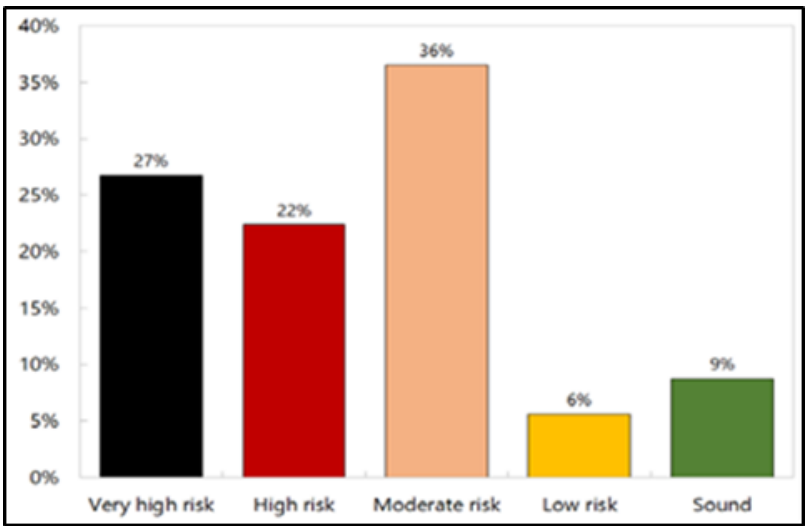

Figure 16. Risk calculation according to the criterion of profitability in state-owned companies, 2015-2017. years (Estimated SOE), (Authors, 2020.)

The analysis shows that more than $78 \%$ of state-owned enterprises fall into the categories of high or very high risk measured by the leverage criterion (Figure 17). Due to the significant fiscal risk under this criterion, assistance to many stateowned gaverment enterprises will be necessary to reduce their debt or embark on significant financial restructuring. „The sectors with the highest profitability risks (ranked as high or very high) are manufacturing (77 percent), mining (75 percent), construction (64 percent), and transportation (53 percent) ${ }^{\text {‘2 }}$.

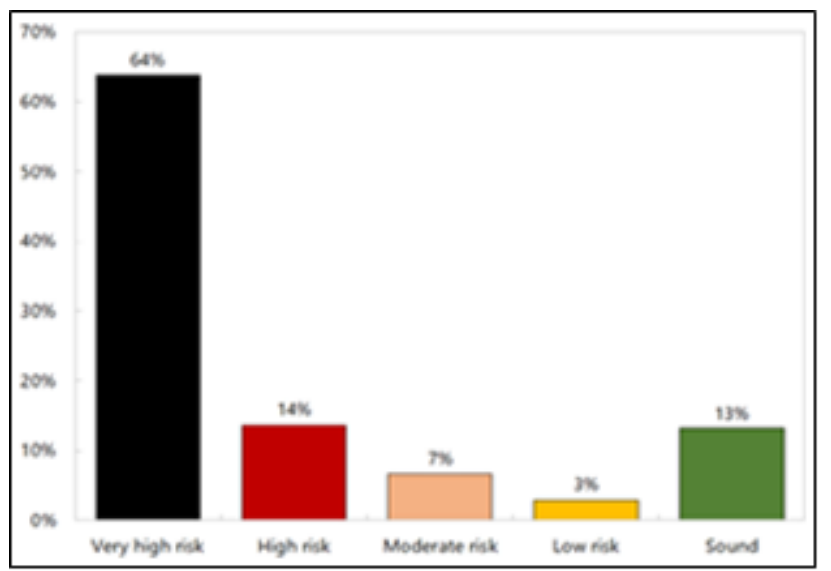

Figure 17. Analysis of indicators of state-owned enterprises measured by the leverage criterion,
2015-2017. years (As a percentage of SOE), (Authors, 2020)

The analysis shows that over $50 \%$ of stateowned enterprises face challenges in settling current liabilities (Figure 18). „This means that almost 50 percent of state-owned enterprises have less current assets than current liabilities, and that they will either have to sell long-term assets, receive budget support, or enter into additional debts to cover their debts that fall due. The sectors with the highest share of high and very high liquidity risks are transport (68 percent), mining (67 percent), manufacturing (60 percent) and construction (57 percent) ${ }^{، 28}$.

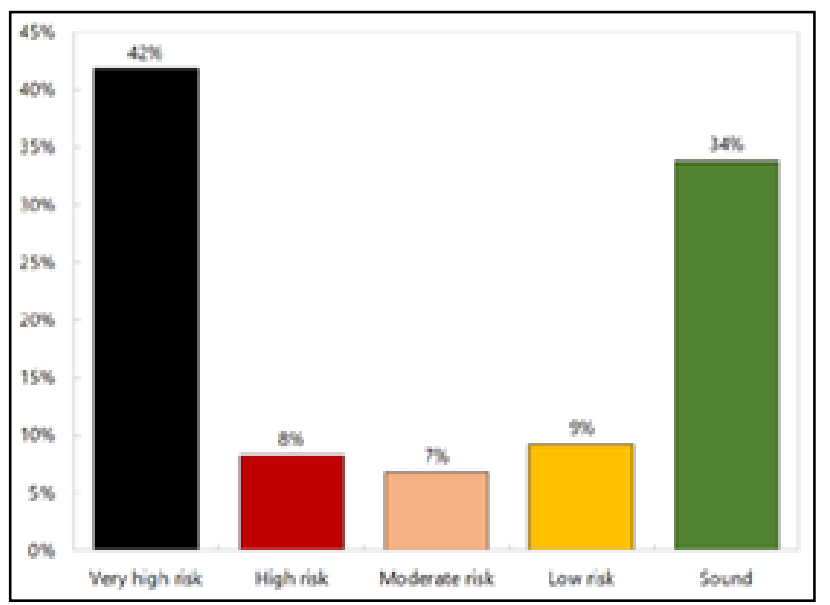

Figure 18. Analysis of risk indicators by leverage criteria, 2015-2017. years

(As a percentage of SOE), (Authors, 2020.)

Table 4 shows the financial ratio analysis of state-owned enterprises, and Table 5 examines the financial risk assessment of the first 20 state-owned enterprises (SOE) and the data for the period from 2015 to 2017.

\footnotetext{
${ }^{27}$ Internet: www.imf.org
}

${ }^{28}$ Internet: www.imf.org 
Table 4. Financial ratio analysis of stateo-wned enterprises (Authors, 2020)

\begin{tabular}{lccc|}
\hline RS & & & \\
& 2015 & 2016 & 2017 \\
\hline ROE & -0.8 & -0.4 & -0.7 \\
Debt/EBITDA & 14.9 & 9.4 & 10.0 \\
CLR & 0.9 & 0.7 & 0.7 \\
ROA & -0.6 & -0.3 & -0.5 \\
\hline
\end{tabular}

\begin{tabular}{|lccc|}
\hline FBiH & & & \\
& 2015 & 2016 & 2017 \\
\hline ROE & -1.2 & 0.1 & 1.0 \\
Debt/EBITDA & 8.2 & 7.1 & 6.7 \\
CLR & 0.8 & 0.8 & 0.9 \\
ROA & -0.8 & 0.1 & 0.6 \\
\hline
\end{tabular}

The results of the research show that 228 state-owned enterprises face high or very high financial risk (Figure 19). Composite indices for state-owned enterprises were made and, based on the criteria of profitability, leverage, the classification of state-owned enterprises into five risk categories was performed.

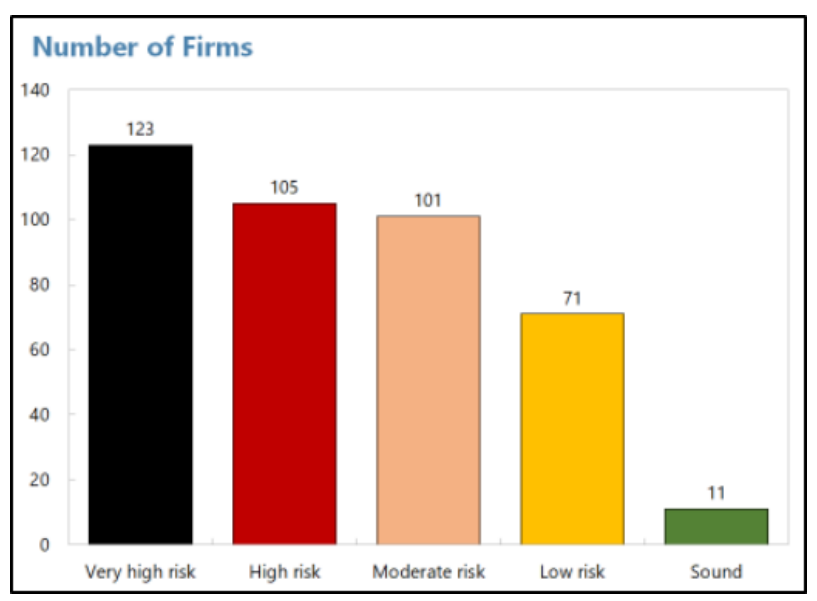

Figure 19. Composite financial risk analysis (authors, 2020)

„Smaller companies and cantonal companies and companies at the central level face slightly higher composite financial risks. The sectors with the largest share of high and very high financial risks are transport ( 74 percent), construction (71 percent) and manufacturing and mining (67 percent) ${ }^{\text {‘29. }}$.

The analysis of the number of employees in state-owned enterprises indicates that approximately 43 thousand workers are employed in state-owned enterprises with high and very high financial risk (Figure 20).

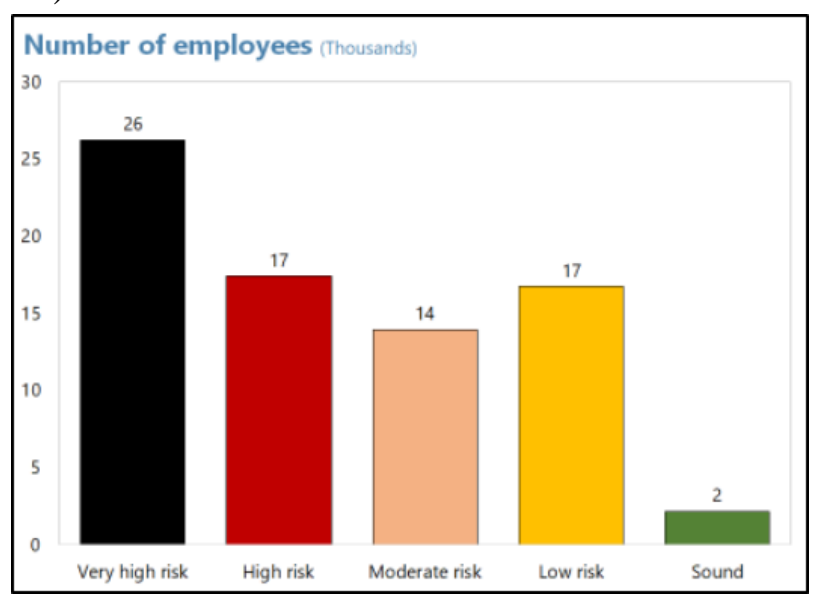

Figure 20: Number of employees in state-owned enterprises (authors, 2020)

It is important to point out that the analysis found that 99 percent of outstanding tax liabilities of state-owned enterprises have companies that are classified as high or very high risk companies (Figure 21).

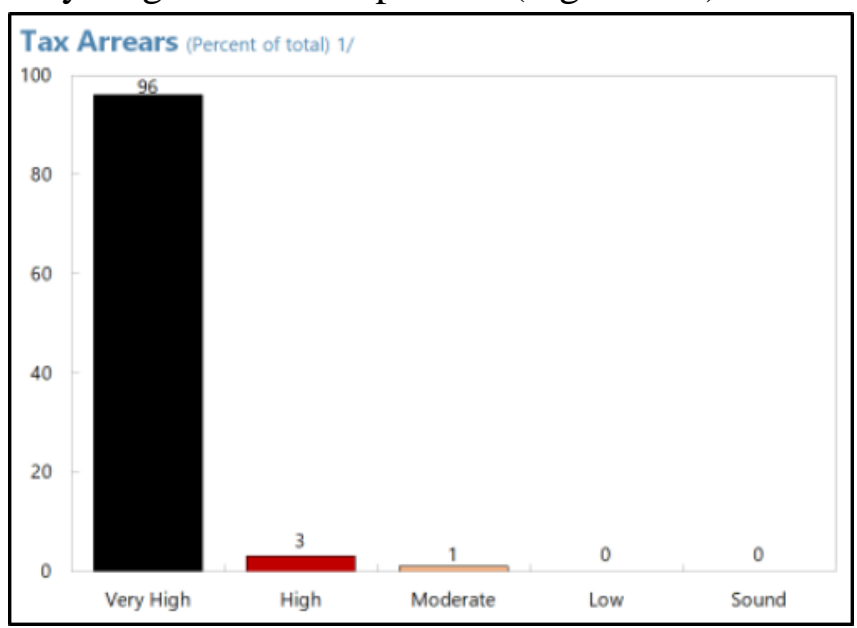

Figure 21. Outstanding tax liabilities of stateowned enterprises (authors, 2020)

${ }^{29}$ Internet: www.imf.org 
Table 5 shows the first 20 state-owned companies in Bosnia and Herzegovina for which a financial risk assessment was performed, for the period from 2015 to 2017.

Table 5. Top 20 SOE: Financial risk assessment, for the period from 2015 to 2017 (Authors, 2020.)

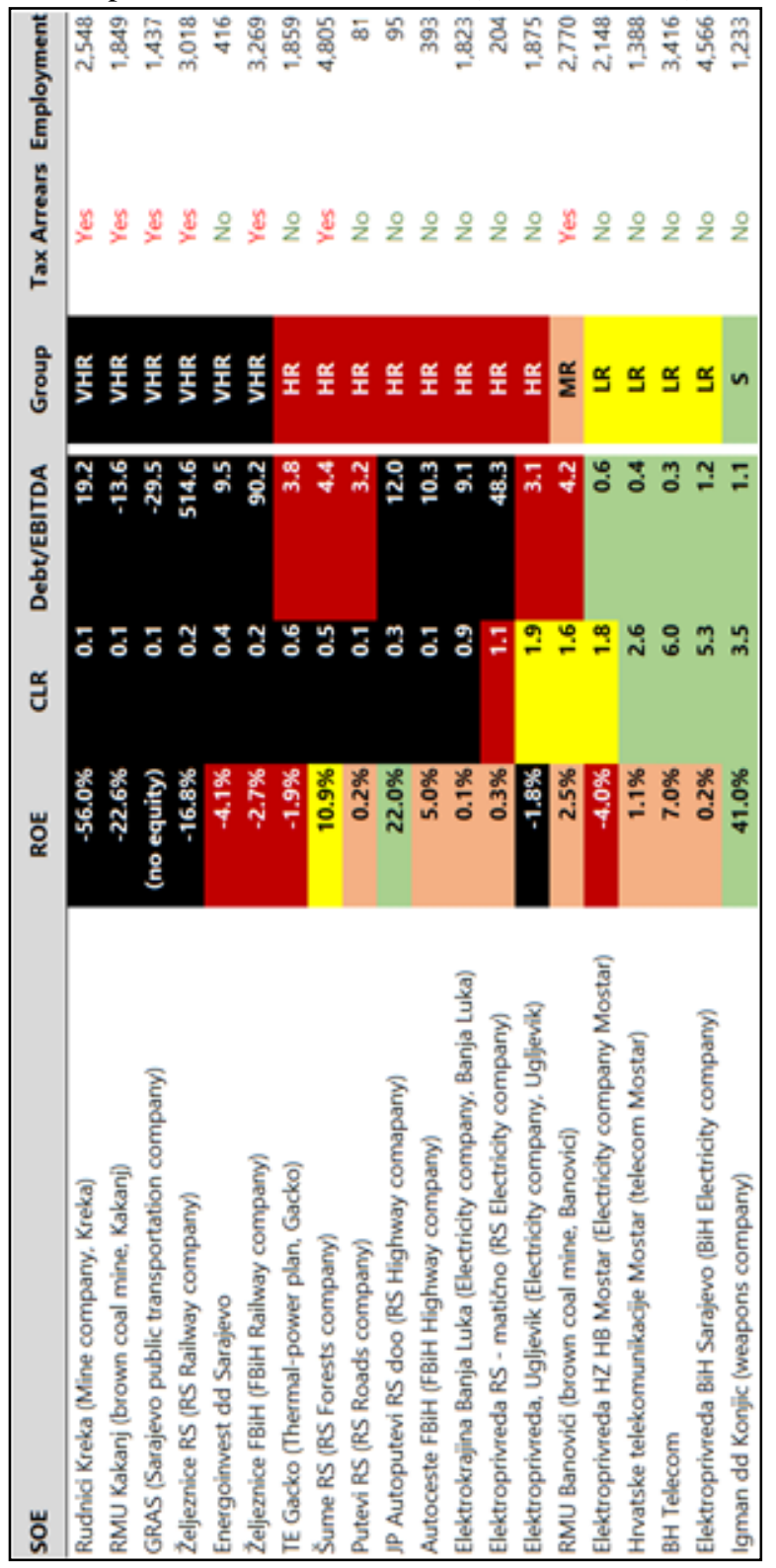

\section{IMPACT OF POTENTIAL GAINS TO EFFICIENCY}

„We estimated opportunity costs by comparing the financial performance of state-owned enterprises in $\mathrm{BiH}$ with the medium levels of the moderate risk category for profitability, leverage and liquidity indicators ${ }^{630}$. High opportunity costs indicate the need to improve efficiency by either increasing revenue or reducing operating expenses. Bosnia and Herzegovina incurs significant opportunity costs by not reforming state-owned enterprises (Table 6).

Table 6. Foregone profits (authors, 2020)

\begin{tabular}{|c|c|}
\hline \multicolumn{2}{|c|}{$\begin{array}{c}\text { Foregone Profits } \\
\text { (million of Euros, average 2015-2017) }\end{array}$} \\
\hline Actual Total Equity & $10,647.6$ \\
\hline Actual Total Net Income & -29.9 \\
\hline Actual ROE & -0.3 \\
\hline Potential ROE & 4.0 \\
\hline Potential Net Income & 425.9 \\
\hline Additional Net Income & 455.8 \\
\hline as GDP percent & 3.0 \\
\hline
\end{tabular}

During the period from 2015 - 2017, actual ROE averaged -0.3 for all state-owned enterprises. In contrast, actual ROE averaged 4.0 in Sweden over the same period, which is coincidentally the middle level in the "moderate risk“ category. „Thus, if state-owned enterprises had generated an average of 4.0 percent in ROE in 2017, net income would have been 3 percentage points of GDP (or $€ 127$ per capita). We can conclude that $\mathrm{BiH}$ governments are giving up up to 3.0 percent of GDP in potential revenue on an annual basis due to inefficiency ${ }^{\text {(31 }}$.

\footnotetext{
30 Internet: www.imf.org

${ }^{31}$ Internet: www.imf.org
} 
At the end of 2017, the unconsolidated debt of state-owned enterprises amounted to 26.6 percent of GDP (Debt / EBITDA = 8.3). For example, for the Debt / EBITDA ratio to reach the target amount, ie the average level, which is 2.5 , the debt would have to be reduced by EUR 2.65 billion (or EUR 750 per person) or, alternatively, EBIDTA would have to to increase by the same amount ${ }^{* 32}$. These estimates suggest that significant debt reductions or operational efficiency improvements are needed to bring the debt of state-owned enterprises to sustainable levels (Table 7).

From the done analysis, we conclude that state-owned enterprises are over-indebted, by close to $18.2 \%$ of GDP.

Table 7. Overindebtedness (authors, 2020)

\begin{tabular}{|c|c|}
\hline \multicolumn{2}{|c|}{$\begin{array}{c}\text { Overindebtedness } \\
\text { (million of Euros, average 2015-2017) }\end{array}$} \\
\hline Actual Total Debt & $3,910.8$ \\
\hline Actual EBITDA & 473.9 \\
\hline Actual Debt/EBITDA & 8.3 \\
\hline Target Debt/EBITDA & 2.5 \\
\hline Target Debt & $1,184.8$ \\
\hline Target Debt Reduction & $2,726.1$ \\
\hline as GDP percent & 18.2 \\
\hline
\end{tabular}

The analysis found that significant balance sheet restructuring is necessary to restore the sector's liquidity. For example, current liabilities should be reduced by about 5.6 percent of GDP to reduce the liquidity ratio to 1.4 (medium level in the moderate risk category) (Table 8).
Tabela 8. Liqidity (authors, 2020)

\begin{tabular}{|c|c|}
\hline \multicolumn{2}{|c|}{$\begin{array}{c}\text { Liquidity } \\
\text { (million of Euros, average 2015-2017) }\end{array}$} \\
\hline Actual Total Current Assets & $1,781.5$ \\
\hline Actual Total Current Liabilities & $2,182.5$ \\
\hline Actual Liquidity Ratio & 0.8 \\
\hline Target Liquidity Ratio & 1.4 \\
\hline Target Current Liabilities & $1,319.3$ \\
\hline Required decrease in c. liabilites & 863.2 \\
\hline as GDP percent & 5.6 \\
\hline
\end{tabular}

\section{MANAGEMENT OF STATE ENTE- RPRISES}

Quality of management of state-owned enterprises can be ensured by the responsibility of the management structure and employees in the enterprise, by supporting transparency and reducing or mitigating fiscal risks. . Transparency is ensured when information on the commercial and non-commercial operations of state-owned enterprises is provided to governments and the public in a timely and regular manner. Accountability is ensured if the work of the managements of state-owned enterprises and the work of their supervisory boards is the subject of consideration in parliaments and in public. Fiscal risks can be qualitatively reduced if financial and operational stability are assessed on a systemic basis.

Quality of management of state-owned enterprises is based on the following pillars:
a) Ownership Policy;
b) Financial oversight;
c) Fiscal linkages.

\footnotetext{
${ }^{32}$ Internet: www.imf.org
} 
The compiled management index was created using answers to questions covering three pillars. The governance index cannot be used to assess the actual implementation of policies, but it can be used to assess uncovered areas in the legal framework and policies on which the stateowned corporate governance framework is based.

The obtained answers to the questions asked in the Federation of Bosnia and Herzegovina and the Republika Srpska place Bosnia and Herzegovina at the bottom of the index list, with extremely low scores for fiscal ties. Most countries in transition that intend to join the European Union must systematically implement significant reforms in order to achieve the highest possible index (Figure 22). NonEU countries in Western Balkans have relatively low index scores, reflecting similarities in state-owned enterprises and the legal framework in those countries.

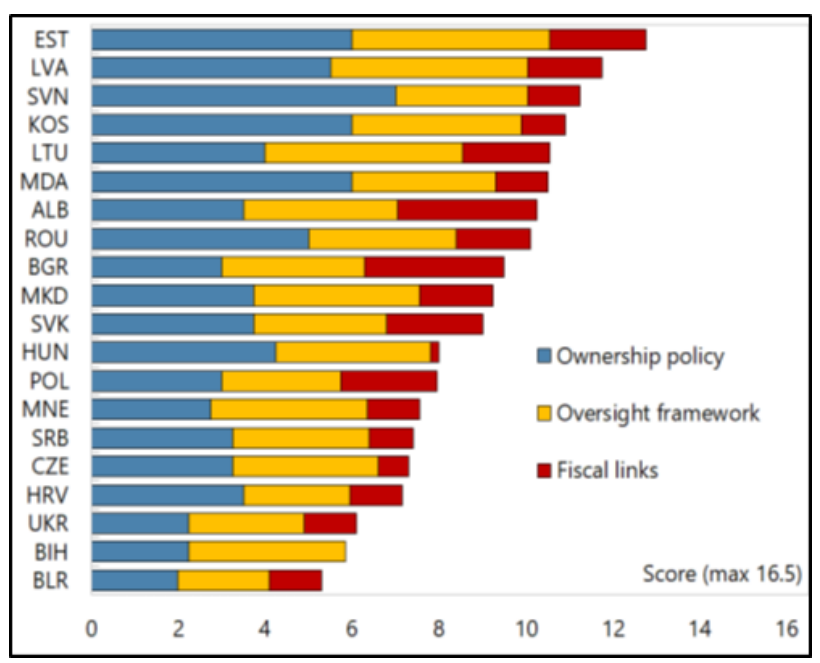

Figure 22. Composite SOE management index, 2018 (Richmond, et. al. 2019)

Responses from the $\mathrm{FBiH}$ and Republika Srpska to the supervision questionnaire indicate persistent weaknesses in the management of state-owned enterprises. The ownership policy and supervisory framework in state-owned enterprises in
Bosnia and Herzegovina have the worst results in the Western Balkans.

\section{CONCLUSION}

In the context of broader reform efforts, the relevant institutions should consider the future of state-owned enterprises, taking into account their relevance to policies and financial performance.

State-owned and non-financially sound state-owned enterprises should be closed, restructured or privatized.

State-owned enterprises that are but financially sound should be privatized. Privatization options include concessions, public-private partnerships (PPPs) and full privatization. The funds generated by privatization are a form of financing and should be subject to reporting, auditing, and parliamentary oversight.

Entity governance frameworks need to be reformed to ensure transparency and accountability. Competent institutions should establish centralized registers of state-owned enterprises, which would include all state-owned enterprises owned by entities, cantons and municipalities.

Policies to depoliticize appointments to SOE boards and management could help improve the performance of SOEs. Financial oversight could be improved through the establishment of centralized oversight units within ministries of finance.

„Fiscal risks arising from SOE should be disclosed. Finally, budget support should only be granted if it is conditional on exante implementation of public sector obligations provided by SOEs, and should not tolerate quasi-fiscal subsidies through arrears of taxes and contributions. social security ${ }^{633}$.

${ }^{33}$ www.imf.org 


\section{REFERENCES}

[1] Renteria, C., Rial, I., Halstead, A., Funke, K., Pautz, M., (2018). „Namibia Assessing and Managing Fiscal Risks from State Enterprises and Public Private Partnerships.“ Fiscal Affairs Department Technical Assistance Report. International Monetary Fund, Washington, DC.

[2] Bower, U., (2017). „State-Owned Enterprises in Emerging Europe: The Good, the Bad, and the Ugly. IMF Working Paper 17/221, International Monetary Fund, Washington, DC

[3] Financial Information Agency of the Federation of Bosnia and Herzegovina :(https://fia.ba/)

[4] Agency for Intermediary, Information and Financial Services of the Republic of Srpska: (https://www.apif.net/ index.php/registri/2015-12-12-14-56.html)

[5] Register of Business Entities of Bosnia and Herzegovina: (https://bizreg.pravosudje.ba/pls/apex/f?p= 183:20:6232106962533052)

[6] Richmond, C., Benedek, D., Cabezon, E., Cegar, B., Dohlman, P., Hassine, M., Jajko, B., Kopyrski, P., Markevych, M., Miniane, J., Parodi, F., Pula, G., Roaf, J., Kyu Song, M., Sviderskaya, M., Turk, R., Weber, S., (2019.). „Reassessing the Role of State- Owned Enterprises in Central Eastern and South Eastern Europe.“. European Departmental Series Paper $19 / 11$.

[7] Sarajevo Stock Exchange:

(http://www.sase.ba/v1)

[8] Di Bella, G., Dynnikova, O., Slavov, S., (2019). „The Russian State's Size and its Footprint: Have They Increased?“. IMF Working Paper 19/53, International Monetary Fund, Washington, DC.

[9] Banja Luka Stock Exchange: https://www.blberza.com/ Pages/Default.aspx

[10] Statistical Office of the Federation of Bosnia and Herzegovina: http://fzs.ba/
[11] World Economic Forum (2015). Global development indicators.

[12] Tax Administration of the Federation of Bosnia and Herzegovina: http://www.pufbih.ba/v1/

[13] Indirect Taxation Authority of Bosnia and Herzegovina:

http://www.new.uino.gov.ba/bs/UIO

[14] Statistical Office of Republika Srpska: http://www.rzs.rs.ba/

[15] Tax Administration of Republika Srpska: https://www.poreskaupravars.org/

[16] Register of Business Entities of Bosnia and Herzegovina:

(https://bizreg.pravosudje.ba/pls

[17] Internet: www.imf.org

[18] Dimova R., (2006). "Monopolistic wages or efficient contracts?", Economics of Transition

[19] Stankovic A., Kulic S., Primorac D.,. (2015). "The impact of foreign direct investment on the unemployment rate in the Republic of Serbia", Megatrend revija

[20] Kraljić A.,, Delismajlović D., Kraljić T., (2013). "Chapter 9 Does Predefined ERP Implementation Methodology Work for Public Companies in Transitioning Country?", Springer Science and Business Media LLC

[21] Perkins F.C., (1996). "Productivity performance andpriorities for the reform of China's state - owned enterprises", Journal of Development Studies.

[22] Internet: www.documents.worldbank.org 
(JPMNT) Journal of Process Management - New Technologies, International Vol. 8, No4, 2020. 